УДК: 574.622;577.161

doi: 10.36359/scivp.2019-20-2.07

\title{
ВПЛИВ ВІТАМІННО-МІНЕРАЛЬНОЇ ДОБАВКИ ДО РАЦІОНУ САМИЦЬ КОРОПА НА ЇХ РЕПРОДУКТИВНУ ФУНКЦЮЮ
}

\author{
К. Б. Смолянінов ${ }^{1}$, канд. с.-г. наук, с. н. с.,

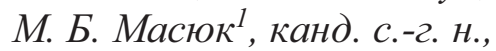 \\ O. I. Вішур ${ }^{1}$, д-р вет. наук, професор, \\ H. 3. Огородник ${ }^{2}$ д-р вет. наук, с. н. с., \\ О. П. Руденко , канд. вет. наук,

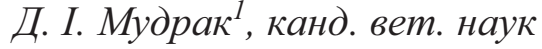 \\ ${ }^{1}$ Інститут біології тварин НААН, \\ вул. В. Стуса, 38, м. Львів, 79034, Україна \\ 2Львівський національний аграраний університет, \\ вул. В. Великого, 1, с. Дубляни Львівської області, 80381, Україна, \\ ${ }^{3}$ Львівський національний університет ветеринарної медицини та біотехнологій \\ імені С. 3. Гжицького \\ вул. Пекарська, 50, м. Львів, 79010, Україна
}

Метою наших досліджень було вивчення впливу різних кількостей жиророзчинних вітамінів $A, D_{3}, E$ і мікроелементів Селену, Цинку $i$ Йоду на показники репродуктивної здатності самиць коропа, а також на деякі ланки метаболізму ліпідів в отриманій від них ікрі та иьоголітках. 3 иією метою в умовах акваріуму було проведено порівняльне дослідження впливу двух різних кількостей жиророзчинних вітамінів та мікроелементів у вигляді добавки до комбікорму самиць у переднерестовий період на обрані показники. Враховуючи показники плодючості та результати біохімічних досліджень ми пропонуємо розробити вітамінно-мінеральну добавку для самиць коропа у переднерестовий період на базі наступних кількостей досліджених сполук: Тривіт у кількості 2500 IO вітаміну А, 5 мг/кг калію йодистого, 40 мг/кг ичнку сульфату та 0,3 мг/кг натрію селеніту.

Ключові слова: ВІТАМІНИ, ЛІПІДИ, ІКРА, ЦЬОГОЛІТКИ, ПРОДУКТИВНІСТЬ/

Вивчення питань, пов'язаних з впливом різних рівнів вітамінів і мікроелементів у раціоні риб на певні ланки метаболізму, знаходиться в центрі уваги дослідників. В останні роки основним напрямком при цьому було вивчення питань, пов'язаних 3 впливом вказаних біологічно-активних сполук на репродуктивну функцію плідників риб та на резистентність отриманого від них потомства. В свою чергу, підвищення рівня жиророзчинних вітамінів в раціоні риб, i, в першу чергу, вітамінів Е і А, з яскраво-вираженою антиоксидантною дією, $є$ необхідною умовою підвищення їх резистентності та репродуктивної функції $[1,2]$. Те саме в повній мірі стосується також ролі мікроелементів, і особливо Селену та Цинку з вираженою антиоксидантною дією, які входять до складу активних центрів антиоксидантних ферментів, таких як супероксиддисмутаза та глутатіонпероксидаза. В результаті наших досліджень у попередні роки було встановлено позитивний вплив добавок жиророзчинних вітамінів та мікроелементів до раціону самок коропа на їх репродуктивну функцію, антиоксидантний та імунний статус організму, на резистентність та інтенсивність росту отриманого від них потомства. У зв'язку з цим актуальним у науково-виробничому плані $\epsilon$ розробка біологічно активної добавки на основі вітамінів та мікроелементів до раціону самок коропа у переднерестовий період. Виходячи із цього, метою наших досліджень було вивчення впливу різних кількостей жиророзчинних вітамінів A, $\mathrm{D}_{3}$, E і мікроелементів Селену, Цинку і Йоду на 
показники репродуктивної здатності самиць коропа, а також на деякі ланки метаболізму ліпідів в отриманій від них ікрі та цьоголітках.

Матеріали і методи. Дослідження проведено у дослідному господарстві Львівського відділення Інституту рибного господарства НААН у с. Великий Любінь Городоцького району Львівської області на трьох групах самиць коропів п'ятирічного віку, які були розділені на контрольну та дві дослідні групи по 7-10 особин у кожній. Риби утримувалися у акваріумах за умов постійної замкненої системи циркуляції води. Самицям коропів контрольної групи за 30 діб до передбачуваного нересту згодовували звичайний гранульований комбікорм. Самицям коропів першої дослідної групи протягом місяця згодовували аналогічний комбікорм з комбікорм з добавками Тривіту у кількості з розрахунку 2500 IO вітаміну А та мікроелементів Йоду, Цинку і Селену у вигляді калію йодистого у дозі 5 мг/кг комбікорму, цинку сульфату у дозі 40 мг/кг та натрію селеніту у кількості 0,3 мг/кг. Самицям коропів другої дослідної групи - комбікорм з добавками Тривіту у кількості з розрахунку 5000 IO вітаміну А та мікроелементів Йоду, Цинку і Селену у вигляді калію йодистого у дозі 10 мг/кг комбікорму, цинку сульфату у дозі 60 мг/кг та натрію селеніту у дозі 0,5 мг/кг.

По закінченні досліду від самиць було одержано зразки ікри, а також зразки печінки і скелетних м'язів цьоголіток, виведених з ікри. В тканинах цьоголіток та ікрі визначали вміст загальних ліпідів ваговим методом після екстракції їх сумішшю хлороформ-метанолу (2:1) за методом Фолча та вміст окремих класів ліпідів методом тонкошарової хроматографії на силікагелі в системі розчинників гексан - диетиловий ефір - оцтова кислота (70:30:1) 3 наступним кількісним їх визначенням біхроматним методом [3].

Результати й обговорення. У таблиці 1 наведено показники, які характеризують відтворювальну здатність самиць коропа, за дії згодовування вітамінно-мінеральної добавки у переднерестовий період. 3 даних, наведених таблиці видно, що всі показники плодючості $€$ вищими у риб дослідних груп порівняно з контролем, що свідчить про позитивний влив вітамінно-мінеральної добавки на господарські показники, які свідчать про репродуктивну здатність самиць коропа а також на показники, які характеризують вихід цьоголіток із отриманої від самиць ікри. Зокрема, встановлено, що абсолютна і відносна плодючість у риб дослідних груп є більшою, порівняно з показниками плодючості риб контрольної групи. При цьому, більш позитивні результати отримано у риб першої дослідної групи, які у переднерестовий період отримували Тривіт і мікроелементи у менших кількостях.

Показники плодючості та виходу цьоголітки за умов згодовування

Таблиия 1 вітамінно-мінеральної добавки у різних кількостях

\begin{tabular}{|l|c|c|c|}
\hline \multirow{2}{*}{\multicolumn{1}{|c|}{ Показники }} & \multicolumn{3}{|c|}{ Групи риб } \\
\cline { 2 - 4 } & Контроль & дослідна 1 & дослідна 2 \\
\hline Абсолютна плодючість, ік/ос. & 308333 & 390000 & 114653 \\
\hline Відносна плодючість, ік/кг & 76320 & 128289 & 13,76 \\
\hline Відносна плодючість, \% & 9,16 & 19,24 & 53 \\
\hline Вихід цьоголітки, \% & 46 & 55 & 38 \\
\hline Середня маса цьоголітки, кг & 61,3 & 65,5 & 36 \\
\hline Загальна маса цьоголітки, кг & 31 & & \\
\hline
\end{tabular}

Натомість, середня і загальна маса цьоголіток була вищою у риб, що були отримані від другої дослідної групу, що свідчить про більшу ефективність згодовування підвищеної кількості вітамінів А, Д, Е і мікроелементів, Йоду, Селену та Цинку на кінцевий вихід цьоголіток.

Нами було проведено дослідження ліпідного складу ікри, отриманої від самиць коропа, яким за місяць до нересту згодовувалася вітамінно-мінеральна добавка, що містить вітаміни A, D, E і мікроелементи Цинк, Селен і Йод у різних кількостях. Результати цих досліджень наведені у таблиці 2. 3 цих даних видно, що згодовування рибам вітамінно-мінеральної 
добавки призводило до збільшення кількості ліпідів у їх складі, при цьому таке зростання було більшим у другій дослідній групі ( $<0,001)$, самиці якої отримували більшу кількість вітамінів і мікроелементів. Оскільки відомо, що ліпіди є основним джерелом поживних речовин в ікрі риб, ці результати слід вважати позитивними і такими, які мають важливе практичне значення для подальшого розвитку молодняку коропа $[4,5]$. Разом з тим, статичстично-достовірних змін співвідношення окремих класів ліпідів при цьому нами встановлено не було.

Таблиия 2

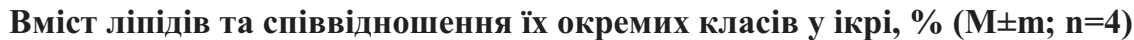

\begin{tabular}{|l|c|c|c|}
\hline \multirow{2}{*}{ Класи ліпідів } & \multicolumn{3}{|c|}{ Групи риб } \\
\cline { 2 - 4 } & Контрольна & дослідна 1 & дослідна 2 \\
\hline Загальні ліпіди & $3,9 \pm 0,1$ & $4,7 \pm 0,07 * * *$ & $25,99 \pm 0,60$ \\
\hline Фосфоліпіди & $27,08 \pm 1,27$ & $27,01 \pm 1,00$ & $17,48 \pm 0,74$ \\
\hline Диацилгліцероли & $16,79 \pm 0,45$ & $17,89 \pm 0,95$ & $28,11 \pm 0,70$ \\
\hline Холестерол & $29,05 \pm 0,85$ & $27,50 \pm 0,56$ & $6,75 \pm 0,55$ \\
\hline НЕЖК & $5,18 \pm 0,67$ & $6,11 \pm 0,37$ & $12,04 \pm 0,53$ \\
\hline Триацилгліцероли & $13,12 \pm 1,05$ & $11,03 \pm 0,64$ & $9,49 \pm 0,28$ \\
\hline Ефіри холестеролу & $8,93 \pm 0,53$ & $10,43 \pm 0,84$ & \\
\hline
\end{tabular}

У таблиці 3 представлені дані отримані при дослідженні ліпідного складу скелетних м'язів цьоголіток, отриманих від риб, яким за місяць до передбачуваного нересту згодовували вітамінно-мінеральну добавку.

Табличя 3

Вміст ліпідів та співвідношення їх окремих класів у скелетних м'язах цьоголіток, \% $(M \pm m ; n=4)$

\begin{tabular}{|l|c|c|c|}
\hline \multirow{2}{*}{ Класи ліпідів } & \multicolumn{3}{|c|}{ Групи риб } \\
\cline { 2 - 4 } & контрольна & дослідна 1 & дослідна 2 \\
\hline Загальні ліпіди & $4,7 \pm 0,1$ & $5,1 \pm 0,08$ & $19,24 \pm 0,08$ \\
\hline Фосфоліпіди & $17,08 \pm 1,5$ & $17,86 \pm 0,93$ & $9,61 \pm 0,49$ \\
\hline Диацилгліцероли & $11,71 \pm 1,13$ & $10,04 \pm 1,1$ & $18,34 \pm 1,06^{*}$ \\
\hline Холестерол & $14,92 \pm 0,87$ & $17,09 \pm 0,74$ & $11,61 \pm 0,77$ \\
\hline НЕЖК & $11,15 \pm 0,24$ & $11,19 \pm 0,58$ & $29,03 \pm 0,86$ \\
\hline Триацилгліцероли & $31,56 \pm 1,02$ & $30,44 \pm 0,91$ & $12,15 \pm 0,55$ \\
\hline Ефіри холестеролу & $13,35 \pm 0,50$ & $13,35 \pm 0,50$ & \\
\hline
\end{tabular}

Встановлено, що згодовування рибам у переднерестовий період вітамінно-мінеральної добавки не призводить до суттєвих змін ліпідного складу у скелетних м'язах цьоголіток, отриманих 3 ïх ікри. Виключення становить лише виявлене нами невелике зростання відносного вмісту вільного холестеролу у риб другої дослідної групи $(\mathrm{p}<0,05)$.

Подібні результати отримані також при дослідженні ліпідного складу печінки цьоголіток, отриманих від риб, яким згодовували різні дози вітамінів і мікроелементів (табл. 4) - зміни вмісту ліпідів і співвідношення їх окремих класів $є$ незначними і статистично недостовірними.

Таблиияя 4

Вміст ліпідів та співвідношення їх окремих класів у печінці цьоголіток, \% $(\mathrm{M} \pm \mathrm{m} ; \mathrm{n}=4)$

\begin{tabular}{|l|c|c|c|}
\hline \multirow{2}{*}{ Класи ліпідів } & \multicolumn{3}{|c|}{ Групи риб } \\
\cline { 2 - 4 } & контрольна & дослідна 1 & дослідна 2 \\
\hline Загальні ліпіди & $4,9 \pm 0,3$ & $4,7 \pm 0,03$ & $16,99 \pm 0,8$ \\
\hline Фосфоліпіди & $17,81 \pm 0,8$ & $19,29 \pm 0,82$ & $10,15 \pm 0,37$ \\
\hline Диацилгліцероли & $10,12 \pm 1,6$ & $9,33 \pm 1,47$ & $17,15 \pm 0,70$ \\
\hline Холестерол & $16,09 \pm 0,98$ & $16,20 \pm 0,96$ & $12,73 \pm 0,70$ \\
\hline НЕЖК & $11,56 \pm 1,37$ & $13,46 \pm 0,78$ & $28,17 \pm 1,03$ \\
\hline Триацилгліцероли & $30,64 \pm 0,64$ & $28,05 \pm 0,99$ & $14,79 \pm 0,73$ \\
\hline Ефіри холестеролу & $13,76 \pm 1,02$ & $13,65 \pm 0,80$ & \\
\hline
\end{tabular}


Таким чином, отримані дані свідчать про те, що згодовування самицям коропа у переднерестовий період вітамінно-мінеральної добавки, що містить жиророзчинні вітаміни А, D, E і мікроелементи Цинк, Селен та Йод суттєво не впливає на ліпідний склад скелетних м'язів та печінки отриманих від них цьоголіток.

\title{
В И С Н О В К И
}

1. Найвищі показники плодючості відмічено у риб першої дослідної групи, які до основного раціону отримували добавку, яка містила Тривіт у кількості 2500 IO вітаміну А, а також 5 мг/кг калію йодистого, 40 мг/кг цинку сульфату та 0,3 мг/кг натрію селеніту.

2. Згодовування у переднерестовий період самицям коропа вітамінно-мінеральної добавки, що містила Тривіт у кількості 5000 IO вітаміну А, а також 10 мг/кг калію йодистого, 60 мг/кг цинку сульфату у та 0,5 мг/кг натрію селеніту призводило до зростання вмісту загальних ліпідів у отриманій від них ікрі.

3. Враховуючи показники плодючості та результати біохімічних досліджень, ми пропонуємо розробити вітамінно-мінеральну добавку для самиць коропа у переднерестовий період на базі такого дозування: Тривіт у кількості 2500 IO вітаміну А, 5 мг/кг калію йодистого, 40 мг/кг цинку сульфату та 0,3 мг/кг натрію селеніту.

Перспективи досліджень. Можливо у подальшому доцільно провести дослідження включення у подібні добавки для самиць коропа додатково інших біологічно активних сполук 3 широким спектром біологічної дії.

\section{THE INFLUENCE OF VITAMIN-MINERAL SUPPLEMENT TO THE DIET OF THE CARP FEMALE ON THEIR REPRODUCTIVE FUNCTION}

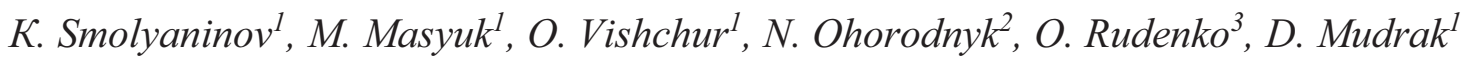 \\ ${ }^{1}$ Institute of Animal Biology of NAAS, \\ 38, V. Stusa str., Lviv, 79034, Ukraine \\ ${ }^{2}$ Lviv National Agrarian University, \\ 1, Volodymyra Velykoho str., Dublyany, 80381, Ukraine \\ ${ }^{3}$ Stepan Gzhytskyi National University of Veterinary Medicine and Biotechnologies, \\ 50, Pekarska str., Lviv, 79010, Ukraine
}

\section{S U M M A R Y}

The increase of the level of fat-soluble vitamins in the diet of fish, and, first of all, vitamins E and $\mathrm{A}$, with a pronounced antioxidant effect, is a necessary condition for elevation of their resistance and reproductive function. The same concerns the trace elements, especially selenium and zinc, with pronounced antioxidant effects, which are part of the active centers of antioxidant enzymes such as superoxide dismutase and glutathione peroxidase. As a result of our previous researches, the positive effect of supplements of fat-soluble vitamins and trace elements in the diet of carp females was found on their reproductive function, antioxidant and immune status of the organism, on the resistance and growth rate of their offspring. In this regard, the development of a biologically-active supplement to the diet of carp females based on vitamins and trace elements in the pre-spawning period is relevant in the scientific and production prospective. Thus, the purpose of our research was to study the effect of different amounts of vitamins $\mathrm{A}, \mathrm{D}_{3}, \mathrm{E}$ and trace elements selenium, zinc and iodine on the reproductive capacity of female carp and on lipid metabolism in their eggs and this year young.

A comparative study of the effect of two different amounts of vitamins and trace elements as a supplement to carps in the pre-spawning period on indicators was conducted in the aquarium conditions. The highest fertility rates were observed in the fish of the first experimental group who 
received a supplement containing $2500 \mathrm{IU}$ of Vitamin A as well as $5 \mathrm{mg} / \mathrm{kg}$ of potassium iodide, 40 $\mathrm{mg} / \mathrm{kg}$ of zinc sulfate and $0.3 \mathrm{mg} / \mathrm{kg}$ of sodium selenite. Feeding at pre-spawning period to females carp with vitamin-mineral supplement containing Trivit in the amount of 5000 IU of vitamin A, as well as $10 \mathrm{mg} / \mathrm{kg}$ of potassium iodide, $60 \mathrm{mg} / \mathrm{kg}$ of zinc sulphate and $0.5 \mathrm{mg} / \mathrm{kg}$ of sodium selenite led to the increase in the content of total lipids in their eggs. As a result, we propose to develop a vitamin-mineral supplement for female carp on the basis of the following compounds tested: Trivitis in the amount of $2500 \mathrm{IU}$ of vitamin A, $5 \mathrm{mg} / \mathrm{kg}$ of potassium iodide, $40 \mathrm{mg} / \mathrm{kg}$ of zinc sulfate, 0.3 $\mathrm{mg} / \mathrm{kg}$ of sodium selenite.

Keywords: VITAMINS, LIPIDS, SPAWN, THIS YEAR CARP, PRODUCTIVITY.

\title{
ВЛИЯНИЕ ВИТАМИННО-МИНЕРАЛЬНОЙ ДОБАВКИ К РАЦИОНУ САМОК КАРПА НА ИХ РЕПРОДУКТИВНУЮ ФУНКЦИЮ
}

\author{
К. Б. Смолянинов ${ }^{1}$, М. Б. Масюк ${ }^{1}$, О. І. Вищур ${ }^{1}$, H. 3. Огородник ${ }^{2}$, О. П. Руденко ${ }^{3}$, Д. І. Мудрак \\ ${ }^{1}$ Институт биологии животных НААН, \\ ул. В. Стуса, 38, г. Львов, 79034, Украина \\ 2Львівський національний аграраний університет, \\ ул. В. Великого, 1, с. Дубляни Львовской обл., 80381, Україна, \\ ${ }^{3}$ Львовский национальный университет ветеринарной медицины \\ и биотехнологий имени С. З. Гжицкого \\ ул. Пекарская, 50, г. Львов, 79010, Украина
}

\section{А Н Н О Т А ЦИ Я}

Целью наших исследований было изучение влияния различных количеств жирорастворимых витаминов $\mathrm{A}, \mathrm{D}_{3}, \mathrm{E}$ и микроэлементов селен, цинка и йода на показатели репродуктивной способности самок карпа, а также на некоторые звенья метаболизма липидов в полученной от них икре и сеголетках. С этой целью в условиях аквариума было проведено сравнительное исследование влияния двух различных количеств жирорастворимых витаминов и микроэлементов в виде добавки в комбикорму самок в преднерестовый период на отдельные показатели. Учитывая показатели плодовитости и результаты биохимических исследований мы предлагаем разработать витаминно-минеральную добавку для самок карпа в преднерестовый период на базе следующих количеств исследованных соединений: Тривита в количестве 2500 ИО витамина А, 5 мг / кг калия йодистого, 40 мг / кг цинка сульфата и 0,3 мг / кг натрия селенита.

Ключевые слова: ВИТАМИНЫ, ЛИПИДЫ, ИКРА, СЕГОЛЕТКИ, ПРОИЗВОДИТЕЛЬНОСТЬ.

\section{Л I T E P A T У P A}

1. Грициняк I. I. Обмін ліпідів у риб : моногр / [I. I. Грициняк, К. Б. Смолянінов, В. Г. Янович] за ред. В. В. Влізла - Львів : «Тріада плюс», 2010. - 335 с.

2. Гринжевський $M$. B. Інтенсифікація виробництва продукції аквакультури у внутрішніх водоймах України / М. В. Гринжевський // К. : Світ, 2000. - 183 с.

3. Кейтс М. Техника липидологии / М. Кейтс // М., 1975. - 260 с.

4. Xue C. ntioxidative activity of carp blood plasma on lipid peroxidation / C. Xue, G. Yu, T. Hirata et al. // Biosci. Biotechnol. Biochem. - 1998. - 62(2). — P. 201-215.

5. Пилипець A. 3. Біохімічний склад, синтетичні і енергетичні процеси у скелетних м'язах коропа різного віку наприкінці літнього і зимового періодів : автореф. дис. на здобуття наук. ступеня канд. с.-г.наук: спец. : 03.00 .04 "Біохімія" / А. З. Пилипець. - Львів, 2003. - 16 с. 


\title{
References
}

1. Hrytsynyak I. I. Lipid metabolism in fish: monogr. / [I. I. Hrytsynyak, K. B. Smolyaninov, V. G. Yanovich] — Lviv : "Triada plus", 2010. - 335 p. (in Ukrainian)

2. Gringevsky M. V. The intensification of aquaculture production in midi-Ukrainian ponds // Kyiv : Svit, 2000. — 183 p. (in Ukrainian)

3. Keits M. Lipidology // Moscow., 1975. — 260 p (in Russian).

4. Xue C. ntioxidative activity of carp blood plasma on lipid peroxidation / C. Xue, G. Yu, T. Hirata et al. // Biosci. Biotechnol. Biochem. - 1998. - 62(2). - P. 201-215.

5. Pylypets A. Z. Biochemical composition, synthetical and energetical processes in skeletal muscles of carp of different age at the end of summer and: Autoref of candidate thesis. : 03.00.04 "Biochemistry — Lviv, 2003. — 16 p. (in Ukrainian)

Рецензент - О. С. Грабовська, к. б. н., с. н. с., ІБТ НААН.

УДК 636.2:636.084

doi: $10.36359 /$ scivp.2019-20-2.08

\section{МОЛОЧНА ПРОДУКТИВНІСТЬ КОРІВ ЗА ВИКОРИСТАННЯ У РАЦІОНАХ ЗИМОВО-СТІЙЛОВОГО ПЕРІОДУ УТРИМАННЯ ВИКО-ЯЧМІННОГО СИЛОСУ}

\author{
Н. М. Федак, канд. біол. наук, с. н. с., \\ I. В. Душара, канд. с.-г. наук
}

Інститут сільського господарства Карпатського регіону НААН

вул. Грушевського, 5, с. Оброшино, Пустомитівський р-н, Львівська обл., 81115, Україна

Показана ефективність згодовування дійним коровам вико-ячмінного силосу (порівняно з кукурудзяним) із нових сортів кормових культур у складі силосно-концентратнокоренеплідного раціону в умовах Карпатського регіону.

Встановлено, щзо використання силосу, заготовленого із озимих ячменю (сорт Широколистий) та вики (сорт Львів'янка) забезпечує потребу дійних корів, згідно з нормою за низкою важливих параметрів живлення (протеїн, Кальцій, Фосфор, Сірка, Мідь, Цинк, Кобальт, Йод). Це сприяє інтенсифікації метаболічних прочесів у рубиі та крові, поліпшує перетравність поживних речовин кормів, у результаті чого підвищується молочна продуктивність корів, якість молока і рівень рентабельності його виробництва.

Ключові слова: ДІЙНІ КОРОВИ, ГОДІВЛЯ, СИЛОС, МОЛОЧНА ПРОДУКТИВНІСТЬ, ЯКІСТЬ МОЛОКА.

Питання рентабельності молочного скотарства, поліпшення якості продукції та зниження іï собівартості тісно пов'язані із повноцінною годівлею худоби $[1,2]$. Основою раціонів для великої рогатої худоби у зимово-стійловий період утримання є силосовані корми. Їх якість - це один із визначальних факторів ефективного використання соковитих кормів у структурі раціонів, а звідси і реалізації генетичного потенціалу тварин. Нині в системі кормовиробництва спостерігається тенденція до зниження в структурі зимових раціонів 